\title{
Vegetation response to southern California drought during the Medieval Climate Anomaly and early Little Ice Age (AD 800-1600)
}

\author{
Linda E. Heusser ${ }^{1}$, Ingrid Hendy ${ }^{2}$ John A. Barron ${ }^{3}$
}

${ }^{1}$ Lamont Doherty Earth Observatory, Columbia University, Palisades, NY 10962 (heusser@1deo.columbia.edu) ${ }^{2}$ Department of Earth and Environmental Sciences, University of Michigan, Ann Arbor, MI, 48109 (ihendy@umich.edu)

${ }^{3}$ U.S. Geological Survey, MS 910, Menlo Park, CA 94025 (jbarron@ usgs.gov)

\section{Abstract}

High-resolution studies of pollen in laminated sediments deposited in Santa Barbara Basin (SBB) core SPR0901-02KC reflect decadal-scale fluctuations in precipitation spanning the interval from AD 800 to 1600. From AD 800 to 1090 during the Medieval Climate Anomaly (MCA) SBB sediments were dominated by xeric vegetation types (drought-resistant coastal sagebrush and chaparral) implying reduced precipitation in the southern California region. Drought-adapted vegetation abruptly decreased at $\mathrm{AD} 1090$ and was rapidly replaced by mesic oak (Quercus) woodlands associated with an increased pollen flux into the basin. After a mesic interval lasting $\sim 100$ years, pollen flux and the relative abundance of Quercus pollen dropped abruptly at AD 1200 when the rapid rise of chaparral suggests a significant drought similar to that of the MCA ( AD 800-1090). This brief resurgence of drought-adapted vegetation between AD 1200-1270 marked the end of the MCA droughts. A gradual increase in mesic vegetation followed, characterizing cool hydroclimates of the Little Ice Age (LIA) in coastal southern California.

The presence of xeric vegetation in SBB coincides with major drought events recorded in tree rings and low lake levels elsewhere in California except for the brief drought between AD 1130-1160. Correlative diatom and terrigenous sediment input proxy records from SBB are largely supportive of the pollen record predominantly linking the MCA with drought and La Niña-like conditions and the LIA with wetter (more El Niño-like) conditions. Differences between paleoclimate proxies (pollen, 
diatoms, and terrigenous sediment) in SBB exist, however, possibly reflecting the temporal and spatial differences in the generation of each proxy record, as well as their individual sensitivity to climate change.

\section{Introduction}

\subsection{California vegetation and climate}

Ecologically and economically damaging extreme weather events - drought and severe storms - characterize the Mediterranean southern California climate (summer drought/winter wet). Predicted future changes in mean annual precipitation and temperature seasonality will likely severely impact western North America tree populations (McLaughlin and Zavaleta, 2012). Some bioclimate studies suggest that regional-scale shifts in vegetation are already occurring. Future water deficits are projected to result in widespread changes in the distribution and composition of southern California ecosystems - the reduction of oak (Quercus) woodlands from their modern range size and displacement, most likely, closer to water (Kueppers, 2005; Sork et al., 2010; McLaughlin and Zavaleta, 2012). However, the distinctive, endemic, droughtadapted vegetation that now characterizes southern California (Axelrod, 1977) has evolved over millions of years of hydroclimate change and may be quite robust in its response to an anthropogenically-forced warmer world.

Regional records of climatically-driven changes in vegetation can serve as templates for the response of southern California ecosystems to future anthropogenicrelated climate change. Pollen-based reconstructions of California climate vary in temporal resolution and scope. During the last interglacial (MIS 5e), pollen deposited in the Santa Barbara Basin (SBB; ODP Hole 893A) from drought-adapted, Mediterranean type vegetation was comparable to or even more expansive than present (Heusser, 1995; Friddell et al., 2002). Low resolution pollen-based reconstructions (ODP Hole 893B) suggest that drought-adapted vegetation also expanded during the Medieval Climate Anomaly (MCA) and shifted gradually toward more mesic Quercus/Pinus woodlands and forests during the Little Ice Age (LIA) at AD 1300-1400 (Heusser, unpublished). Other paleohydrographic proxies from the American southwest also indicate a pattern of longterm drought during the MCA that extended until AD 1360 (Kennett and Kennett, 2000; 
Cook et al., 2004, 2010; MacDonald and Case, 2005; Graham et al., 2007).

Here we present a high resolution, continuous pollen record from AD 800 to 1600 for south coastal California from a new core (Kasten core SPR0901-02KC) collected in 2009 from the SBB. Our unique, high ( $\sim$-year) resolution, coeval terrestrial and marine climate proxy data reveal a complex MCA-LIA transition ( AD 1100 to 1300). In coastal southern California from AD 1100 - 1200, mesic conditions interrupted the prevailing drought. We posit that different paleoproxies have contrasting limitations related to the temporal resolution of the resulting paleoclimate record and differing degrees of sensitivity to different aspects of climate such as temperature, seasonality, and mean annual precipitation.

\subsection{Regional setting}

Tied to large-scale changes in northeast Pacific atmospheric and oceanographic circulation, the Mediterranean climate of the southern California margin is highly seasonal. Precipitation typically occurs in winter when the North Pacific High (NPH) is relatively weak, allowing the subpolar low-pressure systems to migrate southward from the northwest toward California (Haston, 1997). Extreme regional rainfall events, on the other hand, are associated with 'atmospheric rivers' produced by a strong southern branch of the polar jet that tracks warm moist air from the tropics near Hawaii (Browning and Pardoe, 1973; Dettinger, 2011). These extreme precipitation conditions are more prevalent during El Niño events (Andrews et al., 2004) and play an important economic role by filling regional reservoirs. Rainfall is highly coherent throughout the region, as almost all the annual precipitation is produced during large, winter storms. The Santa Barbara coastal region (Fig. 1) receives relatively high rainfall (mean annual precipitation is $\sim 389 \mathrm{~mm}$, but ranges from 250 to $>750 \mathrm{~mm}$ ). This creates an initial brief, intense, sediment-laden discharge to Santa Barbara Channel from the short, steep, coastal watersheds (Nezlin and Stein, 2005) that is followed by delivery of high amounts of suspended sediment from the readily-eroded, weak sedimentary rocks of the Santa Clara and Ventura River drainage basins in the western Transverse Ranges. Dry atmospheric conditions are generally associated with upper level ridging and above normal pressures as the NPH strengthens and migrates poleward in spring-summer (Haston, 1997). 
Surface ocean waters of SBB are primarily influenced by the strength and character of equatorward-flowing California Current (CC). Seasonal poleward movement of the North Pacific High pressure system results in northwesterly winds that induce coastal upwelling and associated fog, which are accompanied by moderate coastal air temperatures and increased effective moisture onshore during spring and summer (Fischer, et al., 2009). Additionally shade from persistent clouds near the coast reduces annual drought stress by 22-40\% (Fischer et al., 2009). By late summer-early fall surface ocean waters reach their highest temperatures in SBB, as the sea surface height gradient from San Diego to Point Conception, north of SBB, increases driving the Southern California Countercurrent (Lynn and Simpson, 1987). Thus ocean surface temperatures in the SBB do not follow the typical seasonal temperature cycle ranging from $\sim 13^{\circ} \mathrm{C}$ in the spring to $\sim 18^{\circ} \mathrm{C}$ in late summer (Hendy, 2004; Barron et al., 2010).

On the coastal plain up to $\sim 300$ m elevation, average air temperature ranges from $\sim 20^{\circ} \mathrm{C}$ in summer to $\sim 9^{\circ} \mathrm{C}$ in winter. At higher elevations in the Santa Ynez Mountains, summer air temperatures average $\sim 10^{\circ} \mathrm{C}$ and winters are mild $\left(7^{\circ} \mathrm{C}\right)$. Average annual precipitation increases upslope from $\sim 451 \mathrm{~mm}$ in Santa Barbara to $\sim 550 \mathrm{~mm}$ in chamise chaparral, $\sim 650 \mathrm{~mm}$ in lower montane oak woodland/forest, and $\sim 1200 \mathrm{~mm}$ on montane peaks ( 1200-1400 m elevation; Wahl, 2003). Furthermore, fog drip at these higher elevations can reduce drought stress by 20-36\% (Fischer et al., 2009). On the highest peaks, winter precipitation may fall as snow, with snowfields lasting until early June (Elford, 1974) providing a spring-early summer source of moisture for vegetation.

The stature, structure, and composition of the natural vegetation of southern coastal California are associated with elevation-related precipitation and temperature gradients. On the marine terraces of the SBB coast and the lower, montane flanks $(<600$ m elevation) a complex mosaic of coastal strand (characterized by Amaranthaceae) and coastal sage scrub (drought-deciduous herbaceous perennials including Artemisia californica, Baccharis, and other Asteraceae) interfingers upslope with chaparral (mainly evergreen, woody, thickly branched shrubs of Adenostoma (chamise), Cercocarpus (mountain mahogany), Ceanothus (California lilac), Rhamnus (buckthorn), Quercus agrifolia (coast live oak) and patches of valley oak $(Q$. lobata, ) and blue oak $(Q$. douglasii) open woodland with grassland. Mesic chaparral that includes scrub oak ( $Q$. 
dumosa, Q. durata) occurs on mid-montane (<900 m) north-facing slopes of the Santa Ynez Mountains. At higher elevations, large, woody oak ( $Q$. dumosa) shrubs, and open Quercus-dominated woodlands are succeeded upslope by open, park-like conifer woodlands or isolated stands of conifers with pine (Pinus ponderosa, P. muricata) and Pseudotsuga macrocarpa (Big-cone Douglas fir). Juniperus (Juniper), Cupressus (Cypress), and Calocedrus (California incense Cedar) may also be present (Critchfield, 1971; Baldwin et al., 2012; Davis et al., 1995). Riparian forests in the SBB drainage are dominated by Quercus, Alnus (alder), Populus (cottonwood), Platanus (sycamore), Salix (willow), and Juglans (walnut).

\subsection{Relationship between pollen in SBB and vegetation onshore}

Modern pollen assemblages from soil, humus and/or moss samples taken in the southern California Coast and Transverse Ranges reflect the composition and topographic distribution of the major vegetation types of the cismontane foothills and mountains (Anderson and Koehler, 2003; Wahl, 2003). These modern pollen spectra, which characterize the major plant communities of coastal California, can serve as modern analogues for paleoenvironmental reconstructions (Wahl, 2003). Pollen deposited offshore also reflects the composition and distribution of regional vegetation onshore and has also been used in paleoreconstructions of past vegetation and climate (Heusser and Balsam, 1977; Heusser, 1983; Byrne et al., 1991; Cole and Liu, 1994; Mensing, 1998; Mensing and Byrne, 1998; Barron et al., 2003; Anderson et al., 2010).

Pollen in SBB sediment reflects aeolian, fluvial, and marine transport and depositional processes. Aeolian pollen dispersal occurs over short distances ( 20-100 m), resulting in a 5- to 10- fold decrease in pollen deposition from source to sink (Solomon and Silkworth, 1986; Jackson and Lyford, 1999). The spatial decline in pollen deposition is complicated by various factors, e.g., wind conditions, topography, and pollen grain size, shape and density (Jackson and Lyford, 1999). For $25 \mathrm{~km}$ beyond the Inyo Mountain Pinus woodland, Pinus pollen deposition was found to be relatively invariant, although deposition dropped 4-fold within $1.5 \mathrm{~km}$ of the woodland (Solomon and Silkworth, 1986). Core SPR0901-02KC is located $\sim 20 \mathrm{~km}$ from the coast of Santa Barbara and $\sim 25 \mathrm{~km}$ 
from either Santa Rosa or Santa Cruz Island; therefore, aeolian pollen dispersal from proximal vegetation to our sampling sites is limited.

Pollen is also transported from regional sources via water and sediments delivered by river runoff. As SBB is the depocenter for extremely, large amounts of terrigenous sediment carried from the watershed by buoyant freshwater plumes and hyperpycnal flow during brief, episodic floods from the Santa Clara river catchment (SC in Fig. 1; Warrick and Milliman, 2003; Warrick et al. 2004; 2007; Kniskern, 2011), fluvial dispersal should be significant. Pollen can be directly deposited into streams and rivers by aeolian dispersal from local vegetation (as discussed previously) and/or by leaf drip, washout, and redeposition via sheetwash. Once deposited in water, pollen behaves in the same manner as clastic particles of similar size and specific gravity (Traverse, 1994). Studies of pollen transport show that fluvial dispersal (primarily during flood events) can carry significant quantities of pollen over long distances (Zhu et al., 2003; Moss et al., 2005; Brown, 2007), and that the major control on the composition of the pollen is the catchment vegetation (Brown, 2007). In exploratory surveys of pollen carried by southern coastal California rivers, pollen concentration ranged from 30 to 1000 pollen grains/liter water (Heusser, unpublished). In fluvial samples taken at different elevations in the San Jacinto River southeast of Los Angeles, pollen assemblages that reflected elevation-related differences in catchment vegetation were integrated in the final depositional site (Heusser, unpublished). Other studies of waterborne pollen in mountainous regions either concur (Solomon et al., 1982; Beaudouin et al, 2007), or suggest that upland species are over-represented in the final depositional site (Zhu et al., 2003).

\section{Materials and Methods}

Kasten core SPR0901-02KC was collected in $588 \mathrm{~m}$ water depth near the center of the SBB $\left(34^{\circ} 16.8^{\prime} \mathrm{N}, 120^{\circ} 02.3^{\prime} \mathrm{W}\right.$; Fig. 1). The 250 -cm-long core was initially surveyed for pollen at broad intervals $(\sim 4 \mathrm{~cm}$ ). Intervals of interest (the MCA and LIA between $65.5 \mathrm{~cm}$ and $138.5 \mathrm{~cm}$ depth) were surveyed for pollen at consecutive $0.5 \mathrm{~cm}$ depth intervals that correspond with an average deposition of five years. XRF scanning and radiocarbon dating were undertaken on nearby cores SPR0901-03KC and SPR0901- 
06KC respectively. Because sediment deposited in the SBB below the oxygen minimum zone has recognizable stratigraphic layers, the three cores were readily correlated. Pollen samples that were processed and analyzed from intervals identified as flood suspensate deposits or turbidites (Schimmelmann et al., 2012; Hendy and Napier, in press) were assigned a corrected depth and single age.

In 1993, an automated, conical sediment trap was deployed in SBB at $540 \mathrm{~m}$ water depth $\left(34^{\circ} 13.9^{\prime} \mathrm{N} 120^{\circ} 01.7^{\prime} \mathrm{W}\right.$; Thunell, 1998). Biweekly samples were subsequently analyzed for pollen from the period August 1993-August 1994. Sediment from core SPR0901-02KC and from this sediment trap was processed using standard procedures (Heusser and Stock, 1984). Known quantities of exotic spores were added to each sample in order to calculate pollen concentrations. At least 300 pollen grains were identified under the light microscope at 400x in $\sim 210$ samples. Disintegrated pollen was rare, as were pollen and spores that were identified as fossil on the basis of morphology or differential staining.

Pollen identifications were based on reference collections of modern pollen and published references. Identification varied taxonomically - from generic to familial levels (taxonomic usage follows Baldwin, et al., 2012). Due to lack of reliable identifying characteristics, the inaperturate pollen grains that are or could have been produced by conifers such as Juniperus or Cupressus are here referred to as Cupressaceae. In like manner, pollen produced by dominant chaparral constituents of the Rosaceae, Rhamnaceae, and Anacardiaceae families (Adenostoma, Cercocarpus, Ceanothus, and Rhamnus) were grouped as RRA. Pinus pollen was primarily diploxylon. Encountered less frequently were Pseudotsuga, Abies, Picea, Salix, Ephedra, Juglans, Platanus, Salvia, Eriogonum, Sphagnum, Selaginella, Isoetes, and members of the Umbelliferae and Onagraceae families. The pollen sum includes pollen of upland and wetland plants. Principal component analysis (PCA) was used to identify the pollen constituents into a set of values of linearly uncorrelated variables. Each constituent was normalized to such that maximum and minimum values fell between 100 and 0 respectively. The loading of each pollen constituent to each principal component (PC) is shown in Supplemental Table 1. Only the first principal component (PC1) is discussed here.

Various age models for SBB sedimentary records have previously utilized the 
well-preserved laminations (varves) and unusually high sedimentation rates (140 $\mathrm{cm} / 1000 \mathrm{yr}$ ) in the basin. However, recent comparison of traditional varve-counts (Schimmelmann et al., 2006) and terrestrial ${ }^{14} \mathrm{C}$ dates generated from twigs and charcoal demonstrate the varve chronology accuracy decreases back through time due to undercounting of years (Hendy et al., 2013). Furthermore, the study demonstrated that the reservoir age required for calibration of marine ${ }^{14} \mathrm{C}$ dates varied by up to 350 years over the last 1,500 years (Hendy et al., 2013). The chronology presented here is based on the high-resolution ${ }^{14} \mathrm{C}$ study that used a companion core (SPR0901-06KC) to resolve the varve and radiocarbon chronology differences of the last 2000 years (Hendy et al., 2013). All years in this publication refer to years AD. In the present study, core depth of SPR0901-02KC was corrected by removal of instantaneous sedimentary events, such as turbidites and flood layers. These basin-wide instantaneous events were employed as stratigraphic markers with sample ages calculated from linear interpolation between each event dated by the new ${ }^{14} \mathrm{C}$ study (Hendy et al., 2013) creating linear sedimentation rates. Mass accumulation rates were calculated using the following equation:

Dry Bulk Density $\left({\left.\mathrm{g}-\mathrm{cm}^{-3}\right)}^{-1}\right.$ Linear Sedimentation Rate $\left(\mathrm{cm}-\mathrm{yr}^{-1}\right) \mathrm{x}$ pollen concentration (1000 grains $\left./ \mathrm{g}^{-1}\right)=$ Mass Accumulation Rate (grains-cm $\mathrm{yr}^{-1}$ )

Dry bulk density of companion core SPR0901-03KC was generated using a Geotek Multisensor Track at the LacCore, Minneapolis, Minnesota (Hendy and Napier, in press). SPR0901-03 KC was scanned with a second generation ITRAX core scanner with a $\mathrm{Cr}$ tube at $200 \mu \mathrm{m}$ resolution for elements $\mathrm{Al}, \mathrm{Br}, \mathrm{Ca}, \mathrm{Cl}, \mathrm{K}, \mathrm{Fe}, \mathrm{Mn}, \mathrm{Rb}, \mathrm{S}, \mathrm{Si}, \mathrm{Sr}, \mathrm{Ti}$, and $\mathrm{Zr}$ at the Large Lakes Observatory, Duluth, Minnesota. The results produced by the ITRAX scanner are output as counts per minute per sample location and should thus be considered only semi-quantitative (Croudace et al., 2006). Principal component analysis (PCA) then converted these elements into a set of values of linearly uncorrelated variables. In SPR0901-03KC, the first principal component (PC1), which explains the majority of the scanning XRF data variance, identified elements associated with the detrital mineral fraction or siliciclastic sediment (Hendy and Napier, in press). Diatom methods are detailed in Barron et al. (2010) and Barron et al. (in press). Counts of at least 300 individuals were made while traversing slides at X790 under the light microscope. In order to reduce the constant sum problem when comparing relative percentage data 
between pollen and diatom proxies, census data have been converted to log-normal values prior to calculating regression statistics.

\section{Results}

3.1 Sediment trap pollen record and its implications

We analyzed pollen collected from the water column by a sediment trap deployed in SBB to determine the present relationship between southern California coastal vegetation and pollen deposition in $\mathrm{SBB}$ in order to validate the use of SBB marine pollen assemblages as paleoclimatic proxies. The flux and relative abundance (\%) of pollen captured in the sediment trap for one calendar year (1993-1994) are shown in Figures 2 and 3. 1993-1994 was a year of average precipitation and runoff. During flood events, river discharge averages 27 times annual discharge during previous dry years (Inman and Jenkins, 1999).

Satellite imagery clearly identifies sediment plumes entering Santa Barbara Channel associated with high river runoff after rainfall events, specifically from the Santa Clara River catchment. Yet, during the 1993-1994 interval collected by the sediment trap, peak pollen flux and peak lithogenic flux apparently lagged peak river discharge by two to three months (Fig 2A and J). Bottom water flow of suspended sediment (including pollen) beneath the level of the sediment trap that was deployed $\sim 50 \mathrm{~m}$ off the bottom (Warrick et al., 2004) may have prevented the capture of the flood plume. Additionally, a delay in sediment deposition in the trap due to re-suspension of previously deposited shelf sediment and/or flocculation of terrigenous material may also have created a lag (Thunell, 1998; Kniskern, 2011).

Pollen assemblages deposited in the SBB sediment trap reflect the composition of the major plant communities onshore (Critchfield, 1971; Anderson and Koehler, 2003; Anderson et al., 2010). The wide distribution of Quercus species in numerous and varied coastal southern California habitats (chaparral, lowland and foothill Quercus woodlands, montane woodland, and riparian woodlands) is mirrored by the high percentage of Quercus pollen in the sediment trap (Barbour and Major, 1977; Bendix, 1994). Pollen from lower elevation biomes - Artemisia (coastal sagebrush), Poaceae (grass), and chaparral - is more abundant than pollen from the small, high-elevation conifer biomes 
with Pinus and Cupressaceae. Coastal strand pollen (Amaranthaceae) is minimal, less than that of riparian vegetation, such as Alnus (alder). Although many processes are involved in pollen transport and deposition, the concentration of pollen deposited in the sediment trap generally represents the abundance of the plant communities in the watershed from which they were derived. The relatively low amount of southern California chaparral (other than Quercus-chaparral) recorded in the sediment trap reflects limited pollen production and dispersal of this closed canopy community (Lewis et al., 1991).

Annual variations in pollen abundance (\%) of key taxa in the regional vegetation types coincide with seasonal variations in pollen production in the SBB watershed (Fig. 3). During the late winter, Alnus and Cupressaceae pollen production peaks, followed by peak production of Pinus (November and late winter-early spring), Quercus (MarchMay), and shrubs and herbs (sage, composites, and Amarathaceae) in summer and fall (Fairley and Batchelder, 1986; Robledo-Aruncio and Gil, 2005; Pluess et al., 2009; AlbaSanchez et al., 2010). Artemisia blooms mainly in fall (Koenig, 2003). The relative abundance of chaparral pollen (in which different components bloom at various times of the year) increases periodically throughout the year. Maximum chaparral pollen in the SBB sediment trap occurs in late spring when the widespread, southern California chamise chaparral (Adenostoma) flowers (Dyer and Liebhaber, 1995). Poaceae pollen abundance in the SBB sediment trap record reflects the flowering of perennial grasslands and open Quercus-grassland following the winter rains. Artemisia forms a mosaic with Poaceae; however, Artemisia does not always follow rainfall patterns and shows optimal pollen production even during droughts (Alba-Sanchez et al., 2010).

Total pollen flux $\left(\mathrm{g}-\mathrm{m}^{-2} \mathrm{day}^{-1}\right)$ in sediment deposited in the SBB trap during March and April 1994 was double the yearly average (Fig. 3). Peaks in Quercus, Poaceae, chaparral, Pinus, Alnus, and Cupressaceae pollen flux were comparable and contemporaneous. Alnus flux was also high during midwinter, as was Cupressaceae flux. Herbaceous vegetation (Amaranthaceae and Asteraceae) and Artemisia (coastal sagebrush) concentration rose during late summer and early fall. As winter rains began, pollen flux gradually decreased and was minimal during the abrupt increase in discharge $\left(\mathrm{m}^{3}-\mathrm{s}^{-1}\right)$ of the Ventura River. 
The 1993-1994 SBB sediment trap pollen data illustrate the importance of fluvial input and the role of multiple vectors in pollen transport and deposition in SBB (Jackson, 2012). Our results concur with numerous studies that showed the importance of fluvial pollen transport to large lakes and marine environments, and with research that showed that pollen assemblages deposited in offshore waters accurately reflect the vegetation onshore (Sanchez Goni, et al., 1999; Moss et al., 2005; Brown, 2007). The close relation between pollen in the SBB sediment trap and catchment vegetation suggests that, despite the uncertainties in deconvolving pollen dispersal and sedimentation processes (Jackson, 2012), pollen deposited in the SBB can be used to reconstruct paleoenvironmental changes in the western Transverse Range of coastal southern California.

\subsection{Pollen record of AD 800 to1600 in core SPR0901-02KC}

The overall pollen record from the AD 800 to 1600 interval (all years hereafter refer to years AD) in SPR-0901-02KC is dominated by pollen from the more numerous, widely-distributed, lower elevation biomes (coastal strand, marsh, and sagebrush; chaparral; Quercus woodland; Fig. 4). Pollen from the smaller, highest elevation conifer biomes (Cupressaceae and Pinus) is relatively less abundant $(\leq 10 \%)$. Chaparral (RRA) pollen is most prominent from $~ 800-1090$ (MCA), with percentages fluctuating above the mean (20\%). At the same time, the relative abundance of Asteraceae exhibits an overall decline. Percentages of Quercus $(<\sim 30 \%)$ and Pinus $(\sim 8 \%)$ are low and monotonic. The late MCA (1090) is marked by a brief, abrupt increase in Pinus and Asteraceae. At 1100, chaparral percentages decrease and remain below those of the early MCA for 100 years. During that century, Quercus dominates, with Quercus percentages (36-39\%) remaining well above the long-term mean. Pinus percentages gradually decrease to close to values of the MCA. High Quercus percentages coincide with low chaparral and Asteraceae relative abundance. Pollen flux hovers below the mean $\left(\sim 880\right.$ grains- $\left.\mathrm{cm}^{-2} \mathrm{yr}^{-1}\right)$ from 800 to 1080 and is above the mean between $\sim 1100-1200$.

Pollen fluxes drop abruptly to low values (430) from 1200-1270. Simultaneously, chaparral flux rises to a broad, sustained peak until 1270 and then declines below mean values at 1340. The relative abundance of Quercus drops rapidly to minimal values $(\sim 20 \%)$ at 1210 , and then begins a 400 -year increase to values like those between $\sim 1100$ - 
1200. Marked by multidecadal peaks close to those at 1100, Pinus percentages remain above the mean between $~ 1300-1600$. High Pinus concentrations coincide with low pollen flux. Pollen flux increases to a mean value of $\sim 770$ grains. Between 1380 and 1600, chaparral and Asteraceae each constitute $20 \%$ of the pollen sum. The first principal component of the pollen constituents explains $21 \%$ of the variance and positively loads the arboreal pollen (Pinus, Cupressaceae, Alnus, and Quercus), while negatively loading the shrubs, herbs, and grasses (Supplemental Table 1). An ordination diagram of the first two principal components (supplementary Fig. 1) graphically displays the positive loading of the clustered mesic pollen and the negative loading of xeric shrub and herb pollen.

\section{Discussion}

\subsection{Pollen record of the MCA and early LIA}

The major vegetation changes recorded in the SPR0901-02KC through the MCA and into the early LIA primarily involve changes in the relative concentration of Quercus and chaparral pollen. Quercus in the southern California region is associated with cool, mesic woodland environments, while shrubs and herbs in the chaparral ecotone occupy warm, xeric shrubland environments. Quercus clearly dominates (35-40\%) the early LIA vegetation and for 100 years ( 1100 to 1200) interrupting the lengthy prominence of shrubs and herbs that generally lasted during the MCA between $\sim 800$ to 1300. Chaparral dominates (20-35\%) during the MCA. Semi-decadal, high-amplitude fluctuations in chaparral during the LIA (after 1300) always remain below the high relative concentrations during the MCA (800-1090).

Although precipitation, and to a lesser degree, temperature are generally considered to be the principal drivers of vegetation distribution in southern California, annual soil water moisture is probably the major limiting factor (Barbour and Major, 1977). Therefore, we interpret the relative concentrations of Quercus and chaparral as proxies for effective soil moisture. Thus, semi-decadal fluctuations in low soil moisture between $~ 800-1090$ and a deep, extended drought between $~ 1200$ and 1300 bracket an unexpected lengthy, interval of increased soil moisture at the end of the MCA. Discovery of this apparently moist century ( 1100-1200) during the late MCA is the most striking 
aspect of our proxy hydroclimate record from SBB (Fig. 4). Previous, comparatively lowresolution ( 46 year average sampling interval), pollen-based hydroclimate reconstructions from ODP Hole 893B in the SBB showed a gradual transition between MCA aridity and increased effective soil moisture in the LIA (Heusser, unpublished). Our high-resolution ( $\sim 5$ year continuous sampling) data from nearby core SPR090102KC reveal a more complex MCA-LIA transition. At 1090, the sequence of droughts that characterize the MCA was abruptly replaced by a century during which effective soil moisture remained above that of the preceding 300 years. Around 1200, soil moisture rapidly dropped to conditions comparable to MCA minima and did not exceed those of the MCA for the next hundred years. The terminal drought of the MCA-LIA transition in SBB coincides with the generally accepted age ( 1300) of the end of the MCA (Lamb, 1965; MacDonald and Case, 2005; Mann, 2009; Diaz, 2011).

4.2 Comparison with coeval proxies within the core

Changes in the composition and distribution of maritime vegetation in the SBB drainage basin during the 800-1600 interval may be closely related to regional oceanicatmospheric change. Coeval samples from core SPR0901-02KC studied for both pollen and diatoms make it possible to directly link variations in marine and terrestrial conditions in SBB (Fig. 5). If we make the assumption that the diatom and pollen assemblages present in the same five-year composite sample represent average, contemporaneous environmental conditions, statistical correlations of the diatom and pollen census data can provide insight into terrestrial-marine linkages. Linear regression of log-normal pollen and diatom census values reveals few strong correlations (Supplemental Table 2). The strongest correlation $(\mathrm{r}=+0.265, \mathrm{n}=82)$ is between the diatom Thalassionema nitzschioides and Asteraceae. Thalassionema nitzschioides is a cosmopolitan species indicative of a shallow thermocline and the cooler surface waters associated with the offshore California Current (Barron et al., 2003; Barron and Bukry, 2007). This T. nitzschioides-Asteraceae correlation is even stronger during the 1100-1300 transitional interval of the late MCA $(r=+0.503, n=34)$. During this interval, a notable positive correlation also exists between T. nitzschioides and coastal sagebrush ( $\mathrm{r}=+0.439$, $\mathrm{n}=34)$, whereas a negative correlation is present between T. nitzschioides and pine $(\mathrm{r}=-$ 
0.471, $\mathrm{n}=34$ ). The $T$. nitzschioides-oak correlation is also negative during this interval, but less so $(\mathrm{r}=-0.317, \mathrm{n}=84)$. These diatom-pollen correlations suggest that during the 1100-1300 interval (the MCA-LIA transition), a stronger California Current (CC) coincided with drier onshore conditions (or more negative Pacific Decadal Oscillation or PDO conditions), whereas wetter (more mesic) onshore conditions were linked with a weakened CC (or more positive PDO conditions). Comparison of the SPR0901-02KC records of the CC proxy, T. nitzschioides, and pollen PC1 is displayed for the interval of 800 to 1600 in Figure 5A \& C.

Hydroclimate variations (severe droughts and extreme regional flood events) can be reconstructed by another terrestrial precipitation proxy from SPR0901-03KC, concentration of elements associated with lithogenic sediment (Hendy and Napier, in press). The first principal component (PC1) of the scanning XRF data contains high loadings for $\mathrm{Ti}, \mathrm{K}, \mathrm{Fe}, \mathrm{Al}, \mathrm{Si}$, and $\mathrm{Rb}$ (Hendy and Napier, in press) that are associated with the detrital mineral fraction (Hendy, 2004). PC1 is interpreted to represent lithogenic input and therefore an annual river runoff signal preserved in the laminae couplets of SBB (Figure 5C). In the $20^{\text {th }}$ Century, scanning XRF PC1 scores closely follows the PDO (Hendy and Napier, in press). Low river runoff during drought conditions is identified between 860-1040, 1130-1170, 1290-1310, and 1420-1460. Intervals of increased Rhizosolenia spp., a diatom proxy for upwelling conditions (Barron et al., in press), in SPR0901-02K coincide with major droughts identified by the siliciclastic record at 11351145, 1290-1300, and at 1448 (Figure 5; Barron et al., in press), supporting the modern association of increased upwelling off California with onshore drought during La Niña conditions.

Figures 4 and 5 imply that the Santa Barbara region during the MCA prior to 1100 was generally characterized by xeric vegetation (Artemisia and chaparral) and a relatively strong CC, with the exception of a brief interval centered around $\sim 900-940$ when the CC was relatively weak. Warm water diatoms increase to $>25 \%$, and upwelling diatoms to $\sim 10 \%$ of the planktonic diatom assemblage of SPR090-02KC within this same 900-930 interval (Barron et al., in press). Thus, in both the pollen- and lithogenic-based proxies, severe drought events characterize the MCA prior to 1040. However, after $\sim 1100$, inconsistencies between proxies are apparent, notably between 1130-1170 during 
the transition between the MCA and the LIA. The systematic offset between the pollen and lithogenic signals may reflect temporal and seasonal differences integrated by each signal.

Expansion in late MCA mesic vegetation at 1090 is identified by increased arboreal pollen (i.e., Alnus, Quercus, Pinus, and Cupressaceae or positive pollen PC1 score) and pollen flux, (Fig. 2). A positive XRF PC1 score from 1040-1130 suggests increased river runoff that is consistent with mesic vegetation expansion; however, negative XRF PC1 scores suggesting decreased runoff from 1130 to 1170 are not. The relative abundance of upwelling diatom (Rhizosolenia spp.) increases to >10\%, while the \% T. nitzschioides proxy indicates a weaker CC between 1130-1160 (Barron et al., in press) during this interval of increased arboreal pollen production. The dramatic increase in xeric vegetation (negative pollen PC1 score) at 1200 suggests a period of extended drought that coincides with an increase in \% T. nitzschioides and CC strength. After 1300, this relationship between pollen and diatoms appears to break down as Quercus concentrations increase during the early LIA during an interval of moderately common $\%$ T. nitzschioides. Flood events return to SBB at 1270 (Hendy et al., 2013), however, intervals of low river runoff interrupt the wetter conditions during the early LIA at 1300 and 1450 .

\subsection{Regional drought comparisons}

Evidence of drought in California during the MCA is not new. Paleoclimatic reconstructions from terrestrial and marine proxies have identified multi-decadal cycles of droughts in southern California between $~ 800-1300$ and between 1350- 1800 (Mensing et al., 2008; Barron et al., 2010). Many, but not all, reconstructions of climate variability in western North America during the 800-1600 interval also posit La Niña-like conditions during the MCA and El Niño-like conditions during the LIA (Seager, 2008; Barron et al., 2010; Cook et al., 2010). MacDonald and Case (2005) and Cook et al. (2010) argue that generally negative PDO prior to 1300 corresponded with extended drought seen in many proxy hydrologic records from the western United States.

During the MCA-LIA transition ( 1100- 1300), however, hydroclimate proxies, such as southern California lake records, imply less consistent precipitation patterns (Fig. 
5F). Stine (1994) compiled detailed data on submerged tree stumps in the eastern Sierra Nevada of California and concluded that extremely severe drought conditions persisted through the MCA. Trees living in Mono Lake for 8-50 years were inundated at 1070 (during the Post Office high stand), with two more inundation events at 1270 (the Rush Delta high stand) and 1400 (the Danberg Beach high stand) occurring with the MCA-LIA transition (Stine, 1990; original radiocarbon ages were recalibrated using CALIB 6.0, Reimer et al., 2009). Interestingly, the $~ 1269$ highstand in Mono Lake coincides with a flood event in SBB sediments, and an earlier highstand between 1100 and 1190) coincides with increased mesic vegetation in SBB catchments (Fig. 5). In coastal southwestern California lakes, high stands in Lower Bear Lake between 1080-1300 (Kirby et al., 2012) and low lake levels at Lake Elsinore from 900 to 1170 (Kirby et al., 2004) overlap a period of increased fluvial input into SBB (1080-1130).

Paleoclimatic reconstructions from marine and terrestrial proxies in SBB core SPR0901-02KC are more complicated. Between 1090-1130 when tree ring records indicate wetter conditions (Cook et al., 2010) and high stands occur in Mono and Lower Bear lakes (Kirby et al., 2012; Stine, 1990), pollen data imply increased soil moisture, which is consistent with increased values of PC1 in the XRF data from SBB and increased river runoff. Coeval diatom data, however, suggest a strong CC, which should be consistent with dry conditions onshore (Barron et al., in press).

During the interval from 1130-1200, arboreal pollen dominated by Quercus indicates continued high soil moisture agreeing with coeval diatom data suggesting a relatively weak $\mathrm{CC}$, which is consistent with wetter conditions onshore (Barron et al., in press). However, elemental composition of the sediment deposited in our SBB core argues for reduced river runoff between 1130-1170, in agreement with the southern California PDSI calculated from tree rings (Fig. 5E; Cook et al., 2010). Strong upwelling during the early part of this interval is supported by high numbers of Rhizosolenia spp. During the later part of the MCA-LIA transition, severe drought conditions from 12001270 indicated by the high chaparral pollen abundance in the SBB agree with the southern California PDSI and the diatom-based proxy for strong CC flow. However, the XRF PC1 river runoff proxy suggests relatively wet conditions (Fig. 5C).

Various reconstructions of severe drought events in coastal southern California 
from SPR0901-02KC therefore disagree during the transition from the MCA to the LIA. The temporal difference in these reconstructions of southern coastal California drought cannot be due to differing age models, as the same robust age model was applied to these proxies. Rather, we suggest that differences between climatic and ecosystem thresholds of the various proxies are responsible (Maslin, 2004; Tzedakis et al., 2004). River runoff requires only a minimum of $\sim 0.5 \mathrm{~cm}$ of rain per precipitation event for a sediment plume to enter the SBB (Nezlin and Stein, 2005), and brief extreme precipitation events, such as atmospheric rivers, may fill reservoirs rapidly (Kirby et al., 2012). In contrast, southern California oaks, which live hundreds of years, may survive multiyear droughts once mature trees are established. The wetter interval from 1090 to 1130 may have provided the conditions for saplings to become established. Additionally under cooler air temperature regimes or with increased coastal fog associated with strong upwelling conditions, established Quercus woodlands may survive years associated with low precipitation. Thus drought stress may have ameliorated for coastal woodlands by coastal fog associated with strong upwelling from 1130-1170 even as tree rings (inland of the Santa Barbara) and river runoff support drought conditions. As extended drought returned at 1200 , no such persistent strong upwelling existed to reduce drought stress on the coastal vegetation.

\subsection{Drought and PDO/ENSO cyclicity}

Agreement between southern Californian drought proxies and in the strength of the $\mathrm{CC}$ in SBB (\% T. nitzschioides) prior to 1100 suggests a strong North Pacific High supporting previous studies that suggest negative PDO/La Niña-like cycles persisted through the MCA (Graham et al., 2007). In contrast with the MCA, mesic vegetation

onshore, frequent flood events and weaker CC strength offshore are characteristic the LIA from 1300-1600. A strongly negative PDO state for the MCA implies cooler SSTs in the eastern North Pacific vs. warmer SSTs in the western North Pacific (Graham et al., 2007; Barron et al., 2010). In like manner, the extended positive phase of PDO during the LIA implies a relative warm northeast Pacific Ocean. However, sea surface temperature reconstructions in $\mathrm{SBB}$ based on differing proxies differ during the last millennia (Kennett and Kennett, 2000; Fisler and Hendy, 2008; Barron et al., 2013). 
Although there are differences in the spatial and temporal occurrence of severe droughts and extreme flood events in southwestern California, hydroclimate reconstructions are consistent with long-term, amplified ENSO patterns - more La Niñalike conditions during the MCA and more El Niño-like conditions during the LIA (Cook et al., 2010). The change to more El Niño-like conditions during the LIA has been attributed to a shift in the North Atlantic Oscillation (Trouet et al., 2009). Model results suggest that forcing of these major climate changes during the 800-1600 interval may also be attributed to variations in solar irradiance and/or $\mathrm{CO}_{2}$ (MacDonald et al., 2008; Cook et al., 2010).

The PDO/ENSO-driven model of North Pacific climate variability may be too simplistic when explaining 800 years of climate variability in annually- (tree-rings and varves) to semi-decadally- (this study) resolved paleoclimate records (Mann, 2009; Kirby et al., 2010). For example, heavy rainfall in southern California in the 2010-2011 winter was associated with atmospheric rivers carrying tropical moisture to the western US - a weather pattern commonly associated with El Niño events. However, La Niña surface ocean conditions occurred in the Pacific at that time. Conflicting hydroclimate proxies highlighted in this study imply that the transition for the MCA to the LIA may have been associated with a breakdown in the ocean-atmosphere circulation patterns that are observed in the $20^{\text {th }}$ century.

\section{Conclusions}

Pollen analyses of bi-weekly sediment samples from a SBB sediment trap deployed during 1993 and 1994 show that marine pollen assemblages reflect the composition and seasonal changes in pollen production of plant biomes onshore and can serve as modern analogs to reconstruct past changes in southern California coastal vegetation and hydroclimates from pollen deposited in SBB.

During the early Medieval Climate Anomaly ( AD 800- 1090), SBB sediments from marine core SPR0901-02KC were dominated by xeric vegetation types (coastal sagebrush and chaparral) that imply reduced precipitation. A rapid, deep decrease in drought-adapted vegetation at 1090 and a concurrent increase in pollen flux and expansion in arboreal pollen dominantly from Quercus biomes mark the beginning of a 
sustained ( 100 year) mesic interval. At $\sim 1200$, the relative abundance of Quercus pollen and pollen flux abruptly decreases to lowest values of the 800-year record, while chaparral pollen increased to MCA abundances, suggesting the recurrence of a significant, prolonged drought. This resurgence of drought-adapted vegetation between 1200-1285 marks the terminal period of the MCA. A gradual rise of pollen from south coastal California mesic, cool hydroclimates (Quercus and Pinus woodlands) follows and continues into the LIA.

Similarities and disparities between marine (diatoms) and terrestrial (pollen, lithogenic sediment) proxies reflect variance in the sensitivity of ecological and environmental thresholds to changes in climatic. Diatom and pollen data from the same composite samples display only weak correlations. Correlations are strongest between 1100 and 1300, where T. nitzschioides, a diatom proxy for the strength of the California Current (CC), is negatively correlated with more mesic pollen proxies (oak and pine) and positively correlated with more xeric proxies (coastal sagebrush and Asteraceae). The first principal component of scanning XRF elemental data from SPR0901-03KC provides another terrestrial precipitation proxy in the form of lithogenic sediment input from river runoff. Patterns of hydroclimate variation in both terrestrial hydroclimate proxies (pollen and XRF data) are similar prior to 1130 and after 1270 when basin sediments record three flood events $(1269,1380,1532)$. However, during the transition from the MCA to the LIA, when pollen-diatom correlations are the strongest, the river runoff proxy disagrees with pollen. Multiple hydroclimate proxies provide robust evidence for intervals of drought during the MCA and increased precipitation during the LIA suggest a more complex pattern of ocean-atmosphere circulation for the transition between the two climate intervals.

\section{ACKNOWLEDGEMENTS}

We would like to acknowledge Robert Thunell for providing sediment trap material and the crew of the R/V Robert Gordon Sproul for assistance in collecting core material. We appreciate the time and thoughtfulness of our editors (Norm Catto, Jeannine St. Jacques, and Scott Starratt) and two anonymous reviewers for Quaternary International. This research was funded by NSF grants OCE-0752093 to ILH and by 
Lamont Doherty Earth Observatory Climate Center grant 4-30802 to LEH.

\section{References}

Alba-Sanchez, F., Sabariego-Ruiz, S., Diaz de la Guardia, C., Nieto-Lugilde, D., De Linares, C., 2010. Aerobiological behaviour of six anemophilous taxa in semi-arid environments of southern Europe (Almeria, SE Spain). Journal of Arid Environments, 74, 1381-1391.

Anderson, R.S., Koehler, P., 2003. Modern pollen and vegetation relationships in the mountains of southern California, USA. Grana, 42, 129-146.

Anderson, R. S., Starratt, S., Jass, R.M.B., Pinter, N., 2010. Fire and vegetation history on Santa Rosa Island, Channel Islands and long-term environmental change in southern California. Journal Quaternary Science, 25, 782-797.

Andrews, E.D., Antweiler, R.C., Neiman, P.J., Ralph, F.M., 2004. Influence of ENSO on Flood Frequency along the California Coast. Journal of Climate 17, 337-348.

Axelrod, D., 1977. Outline history of California vegetation. In: Barbour, M., Major, J., eds., Terrestrial Vegetation of California. John Wiley \& Sons, New York, pp. 139-194.

Baldwin, B.G., Goldman, D.H., Keil, D.I., Patterson, R.T., Rosatti, T., Wilken, D., 2012. The Jepson manual: Vascular plants of California. University of California Press, $1568 \mathrm{p}$.

Barbour, M.G., Major, J., 1977. Terrestrial Vegetation of California. John Wiley \& Sons, New York, 1002 p.

Barron, J.A., Bukry, D., 2007. Development of the California Current during the past $12,000 \mathrm{yr}$ based on diatoms and silicoflagellates. Palaeogeography, Palaeoclimatology, Palaeoecology 248, 313-338.

Barron, J., Bukry, D., Bischoff, J., 2003. A 2000-yr-long record of climate from the Gulf of California. In: West, G. James and Blomquist, Nikki L., eds., Proceedings of the Nineteenth Pacific Climate Workshop, Asilomar, Pacific Grove, CA, March 3-6, 2002, Technical Report 71 of the Interagency Ecological Program for the San Francisco Estuary. pp. 11-31. 
Barron, J., Bukry, D., Field, D., 2010. Santa Barbara Basin diatom and silicoflagellate response to global climate anomalies during the past 2200 years. Quaternary International 215, 34-44.

Barron, J.A., Bukry, D., Field, D.B., 2013. Response of diatoms and silicoflagellates to climate change in the Santa Barbara Basin during the past 250 years and the rise of the toxic diatom Pseudo-nitzschia australis. Quaternary International 310, 140154. doi.org/10.1016/j.quaint.2012.07.02.

Barron, J.A., Bukry, D., Hendy, I.L., in press. High-resolution paleoclimatology of the Santa Barbara Basin during the Medieval Climate Anomaly and early Little Ice Age based on diatom and silicoflagellate assemblages in Kasten core SPR090102KC. Quaternary International. http://dx.doi.org/10.1016/j.quaint.2014.04.020

Beaudouin, C., Suc, J.-P., Escarguel, G., Arnaud, M., Charmasson, S., 2007. The significance of pollen signal in present-day marine terrigenous sediments: The example of the Gulf of Lions (western Mediterranean Sea). Geobios, 40, 159-172.

Bendix, J., 1994. Among-site variation in the riparian vegetation of the southern California Transverse Ranges. American Midland Naturalist, 132, 136-151.

Brown, A.G., 2007. Monitoring fluvial pollen transport, its relationship to catchment vegetation and implications for palaeoenvironmental studies. Review of Palaeobotany and Palynology, 147, 60-76.

Browning, K. A., Pardoe, C. W., 1973. Structure of low-level jetstreams ahead of midlatitude cold fronts. Quarterly Journal of the Royal Meteorological Society 99(422), 619-638.

Byrne, R., Edlund, E., Mensing, S., 1991. Holocene Changes in the Distribution and Abundance of Oaks in California, In: Standiford, R.B., ed., Proceedings of the symposium on oak woodlands and hardwood rangeland management; October 31 - November 2, 1990; Davis, California. Gen. Tech. Rep. PSW-GTR-126. . Pacific Southwest Research Station, Forest Service, U.S. Department of Agriculture, Berkeley, CA.

Cole, K.L., Liu, G.-W., 1994. Holocene paleoecology of an estuary on Santa Rosa Island, California. Quaternary Research 41, 326-335. 
Cook, E.R., Seager, R., Heim, R.R., Vose, R.S., Herweijer, C., Woodhouse, C., 2010. Megadroughts in North America: Placing IPCC projections of hydroclimatic change in a long-term palaeoclimate context. Journal of Quaternary Science, 25, 48-61.

Cook, E., Woodhouse, C., Eakin, C.M., Meko, D., Stahle, D., 2004. Long-term aridity changes in the western United States. Science 306, 1015-1018.

Critchfield, W.B., 1971. Profiles of California Vegetation. Univ. California, Berkeley, CA. USDA Forest Service, Pacific Southwest Research Station. Research Paper PSW-76, 54 p.

Croudace, I. W., Rindby, A., Rothwell, R. G., 2006. ITRAX: Description and evaluation of a new multi-function X-ray core scanner. In: Rothwell, R. G., ed., New Techniques in Sediment Core Analysis: London, Geological Society of London, p. 51-63.

Davis, F.W., Stine, P.A., Stoms, D.M., Borchert, M.I., Hollander, A.D., 1995. Gap analysis of the actual vegetation of California 1. The southwestern region. Madroño, 42, 40-78.

Dettinger, M., 2011. Climate change, atmospheric rivers, and floods in California - a multimodel analysis of storm frequency and magnitude changes 1 climate change, atmospheric rivers, and floods in California - a multimodel analysis of storm frequency and magnitude changes. Journal of the American Water Resources Association, 47, 514-523.

Diaz, H.F., 2011. Spatial and temporal characteristics of climate in Medieval times revisited. Bulletin of the American Meteorological Society, 92, 1487-1500.

Dyer, Z., Liebhaber, N., 1995. 1994 pollen and fungal spore count. Santa Barbara Medical Foundation Clinic, Santa Barbara, CA, 47 p.

Elford, C.R., 1974. The Climate of California. In: van der Leeden, F., Troise, F.L., eds., Climates of the States. Water Information Center, Port Washington, N.Y., pp. 538-594.

Fairley, D., Batchelder, G., 1986. Oak pollen production in northern California. Journal of Allergy and Immunology, 78, 300-307. 
Fischer, D., Still, C.J., Williams, A.P., 2009. Significance of summer fog and overcast for drought stress and ecological functioning of coastal California endemic plant species. Journal of Biogeography, 36, 783-799.

Fisler, J., Hendy, I., 2008. California Current System response to late Holocene climate cooling in southern California. Geophysical Research Letters, 35(9), 1-5.

Friddell, J.E., Thunell, R.C., Heusser, L.E., 2002. Direct comparison of marine and terrestrial climate variability during marine isotope states 6 and 5: Results from Santa Barbara Basin ODP Hole 893A. Paleoceanography 17(2), 1-12.

Graham, N.E., Hughes, M.K., Ammann, C.M., Cobb, K.M., Hoerling, M.P., Kennett, D.J., Kennett, J.P., Rein, B., Stott, L., Wigand, P.E., Xu, Taiyi, 2007. Tropical Pacific - mid-latitude teleconnections in medieval times. Climatic Change, 83, 241-385.

Haston, L., 1997. Spatial and temporal variability of southern California precipitation over the last $400 \mathrm{yr}$ and relationships to atmospheric circulation patterns. Journal of Climate 10, 1836-1852.

Hendy, I.L., 2004. Intermittent existence of a southern Californian upwelling cell during submillennial climate change of the last $60 \mathrm{kyr}$. Paleoceanography 19, DOI: 10.1029/2003PA000965.

Hendy, I.L., Dunn, L., Schimmelmann, A., Pak, D., 2013. Resolving varve and radiocarbon chronology differences during the last 2000 years in the Santa Barbara Basin sedimentary record, California. Quaternary International, 310, 155168.

Hendy, I.L., Napier, T., in press. From extreme rainfall to drought: 250 years of annually resolved detrital sediment deposition in Santa Barbara Basin. Quaternary International.

Heusser, L., Balsam, W.L., 1977. Pollen distribution in the northeast Pacific Ocean. Quaternary Research 7, 45-62.

Heusser, L.E., 1983. Contemporary pollen distribution in coastal California and Oregon. Palynology 7, 19-42.

Heusser, L.E., 1995. Direct marine-terrestrial paleoclimatic correlation of the last 160,000 years: evidence from high-resolution pollen data in marine cores from the 
northeast Pacific Ocean. In: Adam, D.P., Bradbury, J.P., eds., U.S. Geological Survey Open-File Report 95-34, 58-60.

Heusser, L.E., Stock, C.E., 1984. Preparation techniques for concentrating pollen from marine sediments and other sediments with low pollen density. Palynology 8, 225-327.

Inman, D.L., Jenkins,S.A.,1999. Climate Change and the Episodicity of Sediment Flux of Small California Rivers. The Journal of Geology 107, 251-270.

Jackson, S., 2012. Representation of flora and vegetation in Quaternary fossil assemblages: known and unknown knowns and unknowns. Quaternary Science Reviews 49, 1-15.

Jackson, S.T., Lyford, M.E. 1999. Pollen dispersal models in Quaternary plant ecology: Assumptions, parameters, and prescriptions. Botanical Review 65, 39-75.

Kennett, D.J., Kennett, J., 2000. Competitive and cooperative responses to climatic instability in coastal southern California. American Antiquity, 65, 379.

Kirby, M.E., Poulsen, C.J., Lund, S.P., Patterson, W.P., Reidy, L., Hammond, D.E., 2004. Late Holocene lake level dynamics inferred from magnetic susceptibility and stable oxygen isotope data: Lake Elsinore, southern California (USA). Journal of Paleolimnology 31, 275-393.

Kirby, M.E., Lund, S.P., Patterson, W.P., Anderson, M.A., Bird, B.W., Ivanovici, L., Monarrez, P., Nielsen, S., 2010. A Holocene record of Pacific Decadal Oscillation (PDO)-related hydrologic variability in Southern California (Lake Elsinore, CA). Journal of Paleolimnology 44, 819-839.

Kirby, M.E., Zimmerman, S.R.H., Patterson, W.P., Rivera, J.J., 2012. A 9170-year record of decadal-to- multi-centennial scale pluvial episodes from the coastal southwest United States: A role for atmospheric rivers? Quaternary Science Reviews 46, 5765.

Kniskern, T.A., 2011. Coherence of river and ocean conditions along the US West Coast during storms. Continental Shelf Research, 31, 789-805.

Koenig, W.D., 2003. Is pollen limited? The answer is blowin' in the wind. Trends in Ecology \& Evolution, (Amsterdam) 18, 157-159. 
Kueppers, L.M., 2005. Modeled regional climate change and California endemic oak ranges. Proceedings of the National Academy of Sciences 102, 16281-16286.

Lamb, H.H., 1965. The early Medieval Warm Epoch and its sequel. Palaeogeography, Palaeoclimatology, Palaeoecology 1, 13-37.

Lewis, W.H., Dixit, A.B., Ward, W.A. 1991. Distribution and incidence of North American pollen aeroallergens. American Journal of Otolaryngology 12, 205-326.

Lynn, R.J., Simpson, J.J., 1987. The California Current system: The seasonal variability of its physical characteristics. J. Geophys. Res. 92(C12), 12947-12966.

MacDonald, G.M., Case, R.A. 2005. Variations in the Pacific Decadal Oscillation over the past millennium. Geophysical Research Letters 32, L08703.

MacDonald, G.M., Kremenetski, K.V., Hidalgo, H.G., 2008. Southern California and the perfect drought: Simultaneous prolonged drought in southern California and the Sacramento and Colorado River systems. Quaternary International 188, 11-33.

Mann, M.E., 2009. Global signatures and dynamical origins of the Little Ice Age and Medieval Climate Anomaly. Science 326, 1256-1260.

Maslin, M., 2004. Ecological versus climatic thresholds. Science,306, 2197-2198.

McLaughlin, B.C., Zaveleta, E.S., 2012. Predicting species responses to climate change: Demography and climate microrefugia in California valley oak (Quercus lobata). Global Change Biology,18, 2301-3312.

Mensing, S. A., 1998. A 560-year record of Santa Ana fires reconstructed from charcoal deposited in the Santa Barbara Basin, California. Quaternary Research 51(3), 295305.

Mensing, S., Byrne, R. 1998. Pre-mission invasion of Erodium circutarium in California. Journal of Biogeography 25, 757-762.

Mensing, S., Smith, J., Burkle, K., Allan, M., 2008. Extended drought in the Great Basin of western North America in the last two millennia reconstructed from pollen records. Quaternary International 188, 79-89.

Moss, P., Keershaw, P., Grindrod, J., 2005. Pollen transport and deposition in riverine and marine environments within the humid tropics of northeastern Australia. Review of Palaeobotany and Palynology, 134, 55-69. 
Nezlin, N.P., Stein, E.D. 2005. Spatial and temporal patterns of remotely-sensed and field-measured rainfall in southern California. Remote Sensing of Environment 96, 228-345.

Pluess, A., Sork, V., Dolan, B.F., Davis, F., Grivet, D., Merg, K., Papp, J., Smouse, P., 2009. Short distance pollen movement in a wind-pollinated tree, Quercus lobata (Fagaceae). Forest Ecology and Management 258, 735-744.

Reimer, P.J., et al., 2009. Intcal09 and Marine09 radiocarbon age calibration curves, 050,000 years cal BP. Radiocarbon 51(4), 1111-1150.

Robledo -Aruncio, J., Gil, L., 2005. Patterns of pollen dispersal in a small population of Pinus syvestris L. revealed by total-exclusion paternity analysis. Heredity 94, 1332

Sanchez Goni, M.F., Eynaud, F., Turon, J.L., Shackleton, N.J., 1999. High resolution palynological record off the Iberian margin: direct land-sea correlation for the Last Interglacial complex. Earth and Planetary Science Letters 171, 123-137.

Seager, R., 2008. Tropical Pacific Forcing of North American Medieval Megadroughts: Testing the Concept with an Atmosphere Model Forced by Coral-Reconstructed SSTs. Journal of Climate 21, 6175-6190.

Schimmelmann, A., Lange, C. B, Meggers, B.J., 2003, Palaeoclimatic and archaeological evidence for a 200 -yr recurrence of floods and droughts linking California, Mesoamerica and South America over the past 2000 years. Holocene 13, 5, 763778.

Schimmelmann, A., Lange, C., Roark, E.B., Ingram, B.L. 2006. Resources for paleoceanographic and paleoclimatic analysis: A 6,700-Year stratigraphy and regional radiocarbon reservoir-age $(\mathrm{R})$ record based on varve counting and ${ }^{14} \mathrm{C}$ AMS dating for the Santa Barbara Basin, offshore California, U.S.A. Journal of Sedimentary Research 76, 74-80.

Schimmelmann, A., Hendy, I., Dunn, L., Pak, D.K., Lange, C., 2012. Revised 2000year chronostratigraphy of partially varved marine sediment in Santa Barbara Basin, California. Geologiska Fóreningen 135, 258-264.

Solomon, A.M., Blassing, T.J., Solomon, J.A., 1982. Interpretation of floodplain pollen in alluvial sediments from an Arid Region. Quaternary Research 18, 52-71. 
Solomon, A.M., Silkworth, A.B., 1986. Spatial patterns of atmospheric pollen transport in a montane region. Quaternary Research 25, 150-162.

Sork, V.L., Davis, F.W., Westfall, R., Flint, A., Ikegami, M., Wang, H., Grivet, D., 2010. Gene movement and genetic association with regional climate gradients in California valley oak (Quercus lobata Née) in the face of climate change Molecular Ecology 19, 3806-3823.

Stine, S., 1990. Late Holocene fluctuations of Mono Lake, eastern California. Palaeogeography, Palaeoclimatology, Palaeoecology 78, 333-381.

Stine, S., 1994. Extreme and persistent drought in California and Patagonia during mediaeval time. Nature, 369, 546-549.

Thunell, R., 1998. Particle fluxes in a coastal upwelling zone: sediment trap results from Santa Barbara Basin. Deep-Sea Research II, 45, 1863-1884.

Traverse, A., 1994. Sedimentation of Organic Particles. Cambridge University Press, Cambridge, $544 \mathrm{p}$.

Trouet, V., Esper, J., Graham, N., Baker, A., Scourse, J., Frank, D.C., 2009. Persistent positive North Atlantic oscillation mode dominated the Medieval Climate Anomaly. Science 324, 78-80.

Tzedakis, P.C., Roucoux, K.H., de Abres, L., Shackleton, N.J., 2004. The duration of forest stages in southern Europe and interglacial climate variability. Science 306, 2231-2235.

Wahl, E.R., 2003. Pollen surface samples for paleoenvironmental reconstruction from the coast and Transverse Ranges of southern California. Madroño 50, 286-399.

Warrick, J.A., Milliman J.D., 2003. Hyperpycnal sediment discharge from semiarid southern California rivers: Implications for coastal sediment budgets. Geology 31, 781-784.

Warrick, J.A., Mertes, L., Washburn, L., Siegel, D., 2004. A conceptual model for river water and sediment dispersal in the Santa Barbara Channel, California. Continental Shelf Research, 24, 2029-3043.

Warrick, J.A., DiGiacomo, P., Weisberg, S.B., Nezlin, N.P., Mengel, M., Jones, B., Ohlmann, J., Washburn, L. G., Terrill, E., Farnsworth, K., 2007. River plume 
patterns and dynamics within the Southern California Bight. Continental Shelf Research 27, 2427-3448.

Zhu, Y., Xie, Y., Cheng, B., Chen, F., Zhang, J., 2003. Pollen transport in the Shiyang River drainage, arid China. Chinese Science Bulletin 48, 1499-1506.

Figure 1. Map of the Santa Barbara Basin (SBB) showing the location of core SPR090102KC, the dominant vegetation types in nearby coastal regions (http://www.californiaherps.com/images/vegetationmapjeaster.jpg; see shading in key), and the drainage basins of rivers emptying into the SBB outlined by red dashed lines (M = Santa Ynez Mountain Range streams; SY = Santa Ynez River, V = Ventura River; SC $=$ Santa Clara River). Shaded bathymetry is in $200 \mathrm{~m}$ increments.

Figure 2. Comparison of sediment and pollen fluxes in the Santa Barbara Basin sediment trap $\left(34^{\circ} 13.9 \mathrm{~N} 120^{\circ} 01.7 \mathrm{~W}, 540 \mathrm{~m}\right.$ water depth; Thunell, 1998). A. Lithogenic (solid black line) and carbonate (dashed red line), B. organic carbon (dashed green line) and biogenic silica (solid pink line) fluxes in $\mathrm{g}-\mathrm{m}^{-2} \mathrm{day}^{-1}$ are compared to C. Poaceae (grass, solid orange line), D. Quercus (oak, solid green line), E. Pinus (pine, solid red line), F. Alnus (alder, solid blue line), Cupressaceae (juniper, dashed green line), G. Asteraceae (solid green line), Artemisia (coastal sagebrush, dashed red line), H. Amaranthaceae (salt tolerant, dashed light blue line), I. chaparral (solid orange line) fluxes in grains $-\mathrm{g}^{-1} \mathrm{day}^{-1}$. Pollen (solid red line) flux is compared to the Ventura river discharge (shaded blue bars) and precipitation (black lines to zero) recorded in Santa Barbara. The Santa Ana wind event of October 20, 2003 is indicated by an open square, while wave events are shown by open triangles and maximum river discharge by solid blue box at the top of the graph. Vertical dashed lines indicate months, with the new year indicated by a solid line. Flowering seasons for Pinus (solid red box), Alnus (solid blue box), Quercus (solid green box) and Asteraceae, Amaranthaceae, and Poaceae (solid orange box) are shown at the bottom of the graph.

Figure 3. Comparison of the relative contributions of sediments and pollen to the Santa Barbara Basin sediment trap (34⒔9N; 12001.7W; $540 \mathrm{~m}$ water depth; Thunell, 1998). 
A. Lithogenic (solid black line), carbonate (dashed red line), B. organic carbon (dashed green line) and biogenic silica (solid pink line) percentages are compared to C. Poaceae (grass, solid orange line), D. Quercus (oak, solid green line), E. Pinus (pine, solid red line), F. Alnus (alder, solid blue line), Cupressaceae (juniper, dashed green line), G. Asteraceae (aster, solid green line), Artemisia (coastal sagebrush, dashed red line), $\mathrm{H}$. Amaranthaceae (salt tolerant, dashed light blue line), I. chaparral (solid orange line) percentages and J. The Ventura River discharge (shaded blue bars) and precipitation (black lines to zero) recorded in Santa Barbara. The Santa Ana wind event of October 20, 2003 is indicated by an open square, while wave events are shown by open triangles and maximum river discharge by solid blue box at the top of the graph. Vertical dashed lines indicate months, with the new year indicated by a solid line. Flowering seasons for Pinus (solid red box), Alnus (solid blue box), Quercus (solid green box) and Asteraceae, Amaranthaceae, and Poaceae (solid orange box) are shown at the bottom of the graph.

Figure 4. Comparison of relative pollen abundance (\%) for the interval (AD 800 to 1600) from the Medieval Climate Anomaly (MCA, AD 800-1200) to the early part of the Little Ice Age (LIA, AD 1300-1600). A. Quercus (oak, green line), B. chaparral (orange line), C. Poaceae (grass, orange line), D. Pinus (pine, red line), E. Alnus (alder, solid blue line), F. Cupressaceae (juniper, dark green line), G. Artemisia (coastal sage brush, red line), H. Asteraceae (aster, light green line), I. Amaranthaceae (salt tolerant, light blue line) percentages and J. pollen flux in grains $-\mathrm{g}^{-2} \mathrm{day}^{-1}$ (gray bars). Massive gray flood events (solid blue lines) and turbidites (dashed brown line) are indicated by vertical lines. Dry intervals as identified by changes in relative pollen abundances, are indicated by tan shaded boxes.

Figure 5. Comparison of the first principal component of the normalized pollen abundances with regional drought indicators for the interval (AD 800 to 1600) from the Medieval Climate Anomaly (MCA) to Little Ice Age (LIA). A. First principle component (PC1) of pollen where high scores reflect arboreal pollen (red shading), and low scores reflect shrub, herb, and grass pollen (blue shading), B. Rhizosolenia spp. (green line) and C. Thalassionema nitzschioides (light blue line). D. The first principal component (PC1) 
of scanning XRF elemental data loaded by elements associated with silicilastic sediments. E. Pollen flux in grains $/ \mathrm{g}^{2} /$ day (grey bars) and F. the Palmer Drought Index (PDSI) for the gridded tree-ring network surrounding Santa Barbara Basin (grids 48, 60 and 61; Cook et al., 2004, 2010). G. Lake levels for southern California lakes as indicated by sediment deposition or lake geochemistry (Kirby et al., 2004, 2012) and Mono Lake, where 1. L.S. = Lee Vining low stand, 2. H.S. = Post Office high stand, 3. L.S. = Simis Ranch low stand, 4. H.S. = Rush Delta high stand, 5. LS. = 10 mile low stand and 6. H.S. $=$ Danberg Beach high stand (Stine, 1990). ${ }^{14} \mathrm{C}$ Ages for Mono Lake high stands were recalibrated with the highest probability mean age displayed as a shaded star, and other probabilities as open stars (Reimers et al., 2009). Massive grey flood events (solid blue lines) and turbidites (dashed brown line) are indicated by vertical lines. Blue shaded bars represent intervals of positive pollen PC1 scores. 
Figure 1

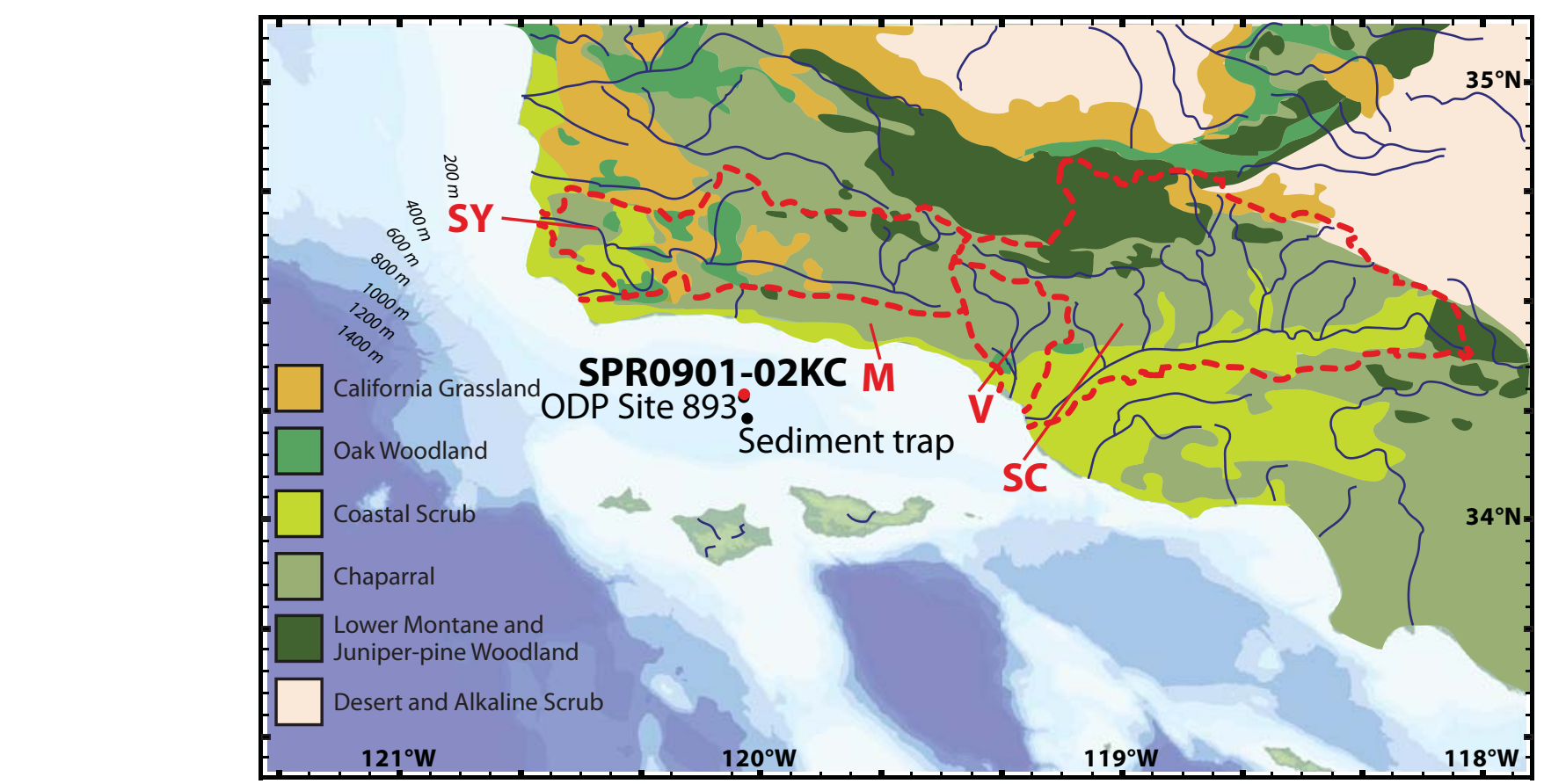

SPRO901-02KC M
Oak Woodland
Coastal Scrub
$\square$ Chaparral
Lower Montane and
Juniper-pine Woodland

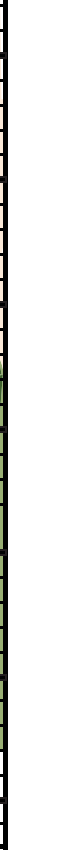
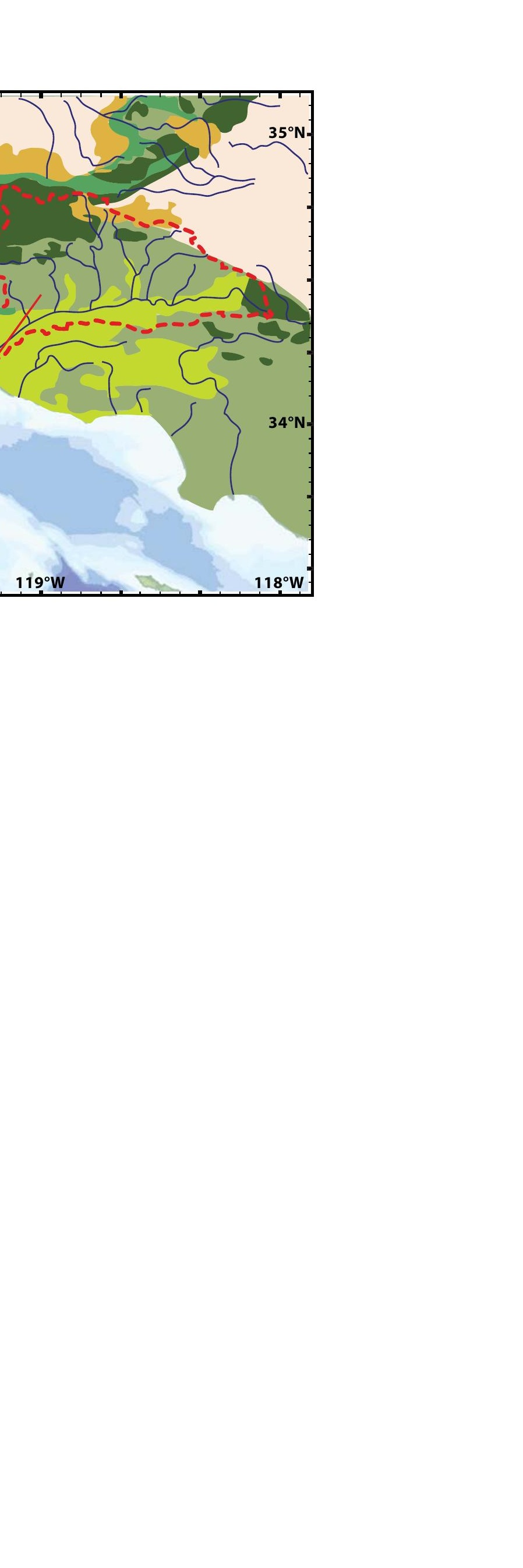


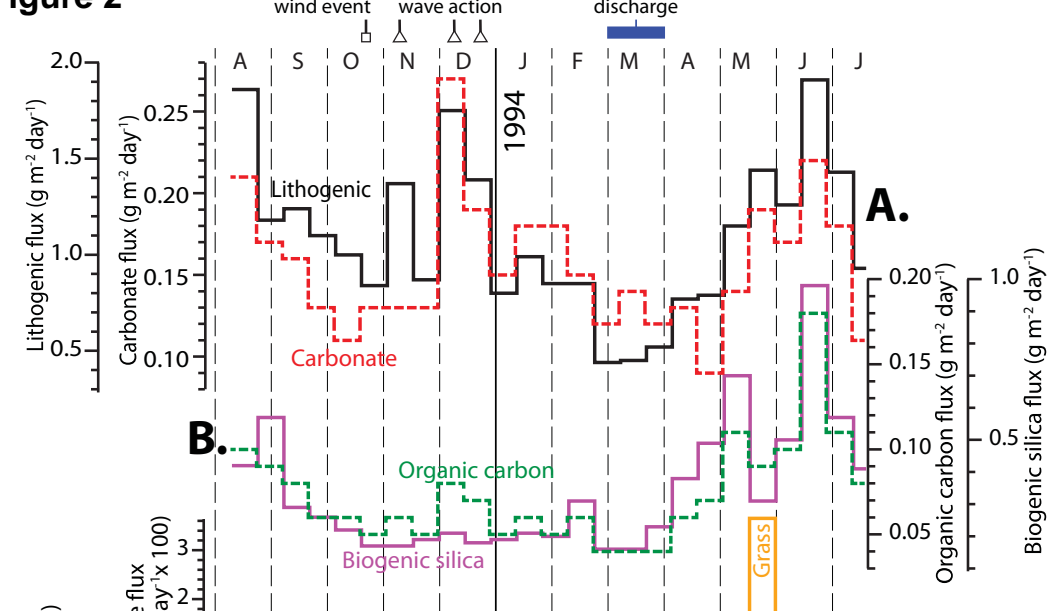

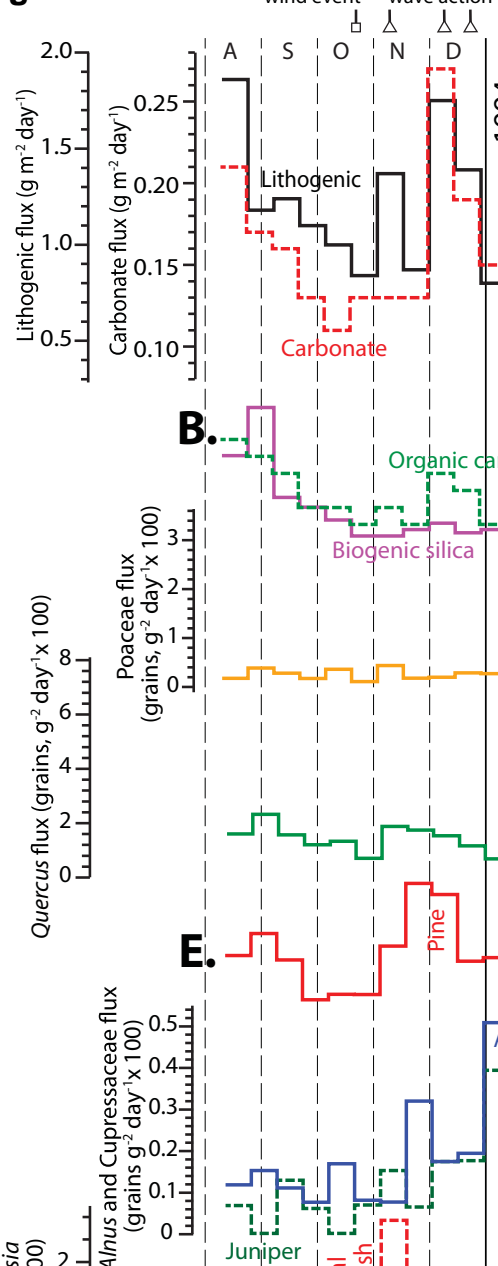

C.

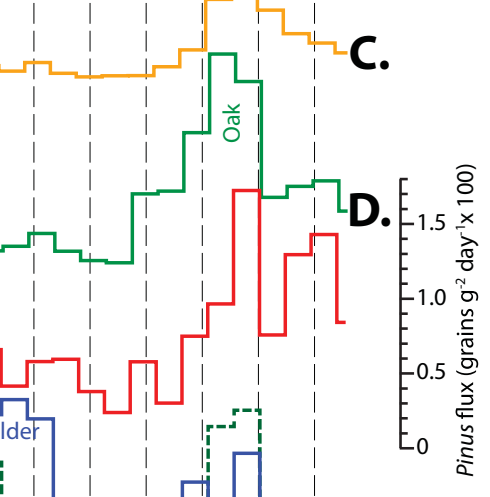

过

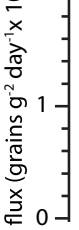

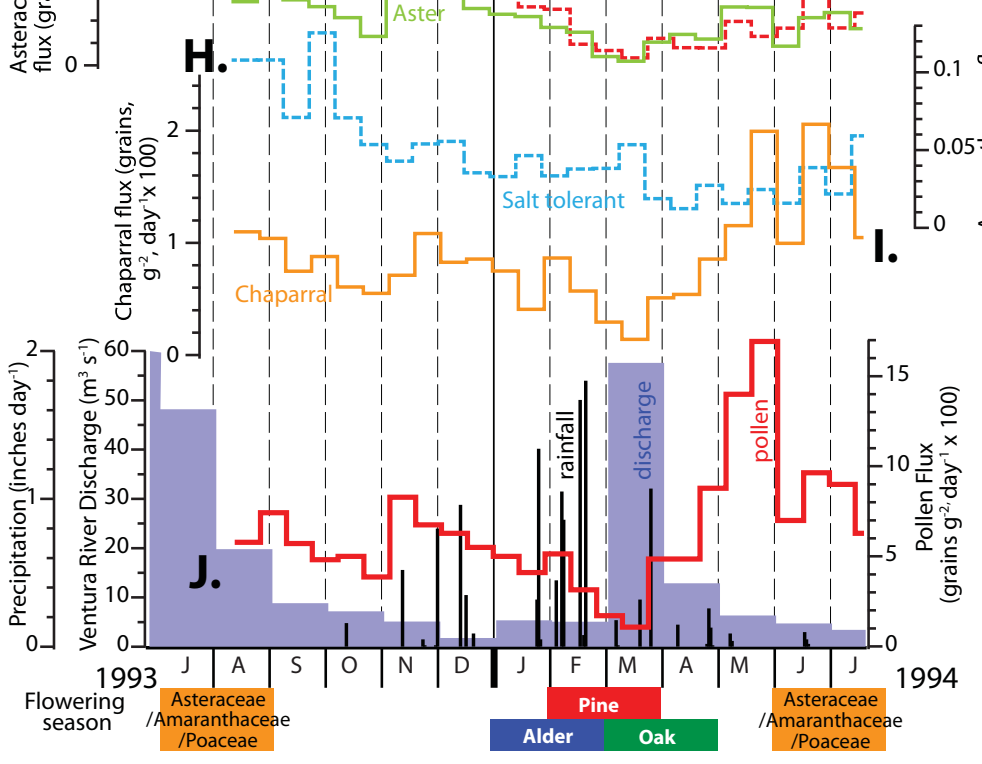




\section{Figure 3}

Santa Ana Increased

Maximum river

wave action

A.

ब-
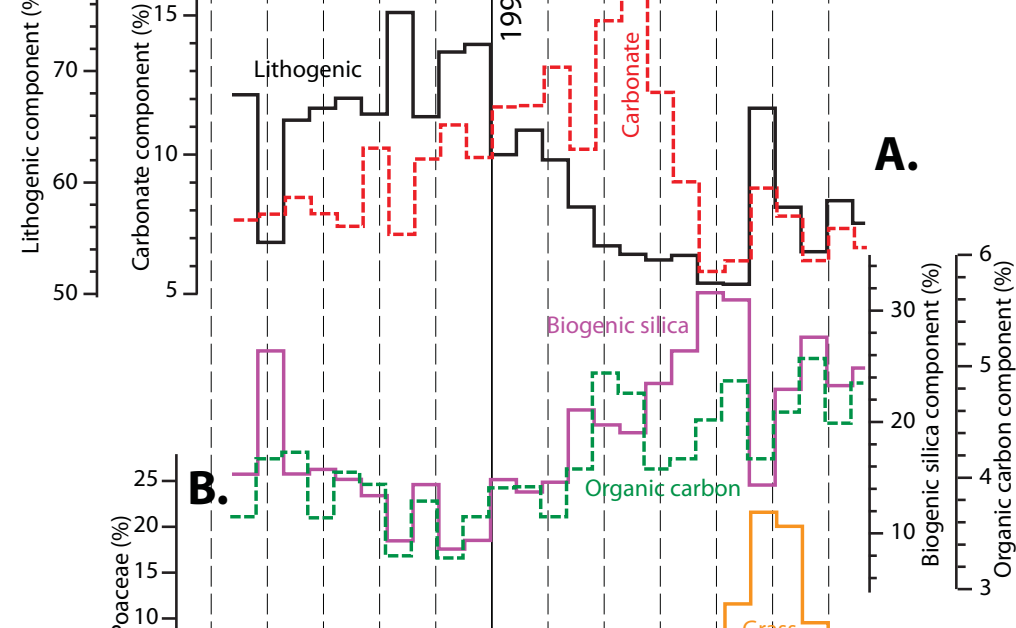

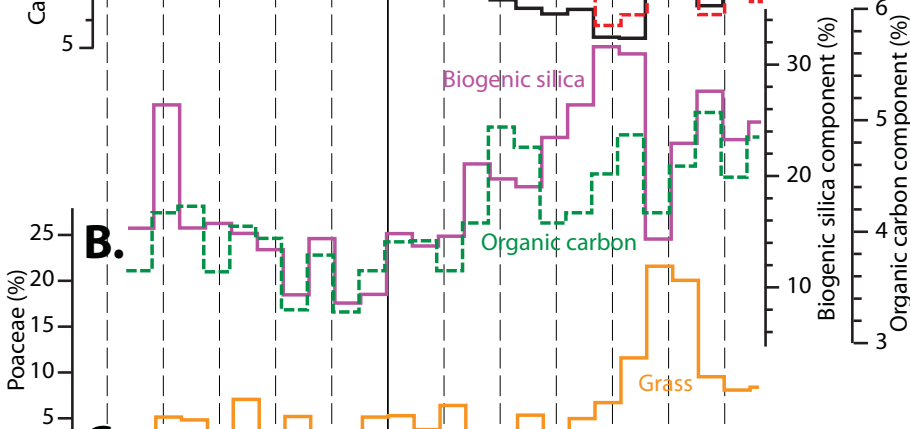
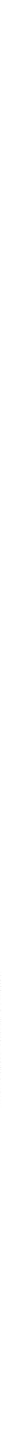

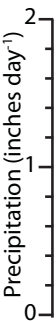

은

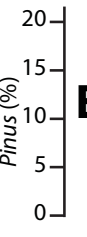

Lithogenic

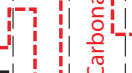
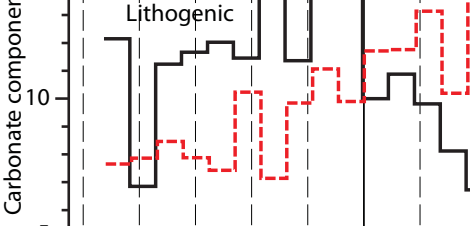

\begin{tabular}{llll} 
& 1 & 1 \\
\hline & 1 & 1
\end{tabular} $\sum^{0}$ 


\section{Medieval Climate Anomaly
Fiaure 4}

Little Ice Age

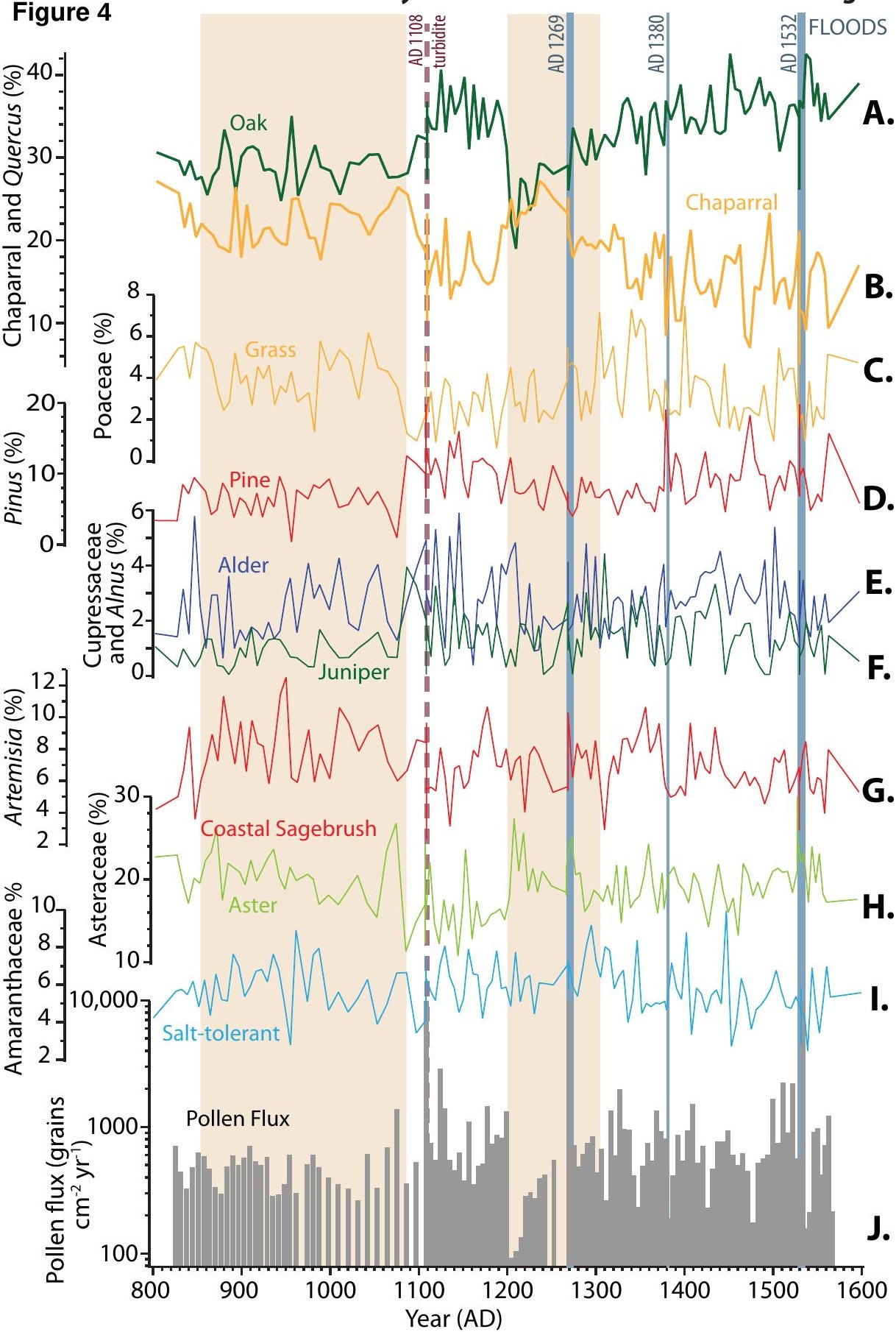



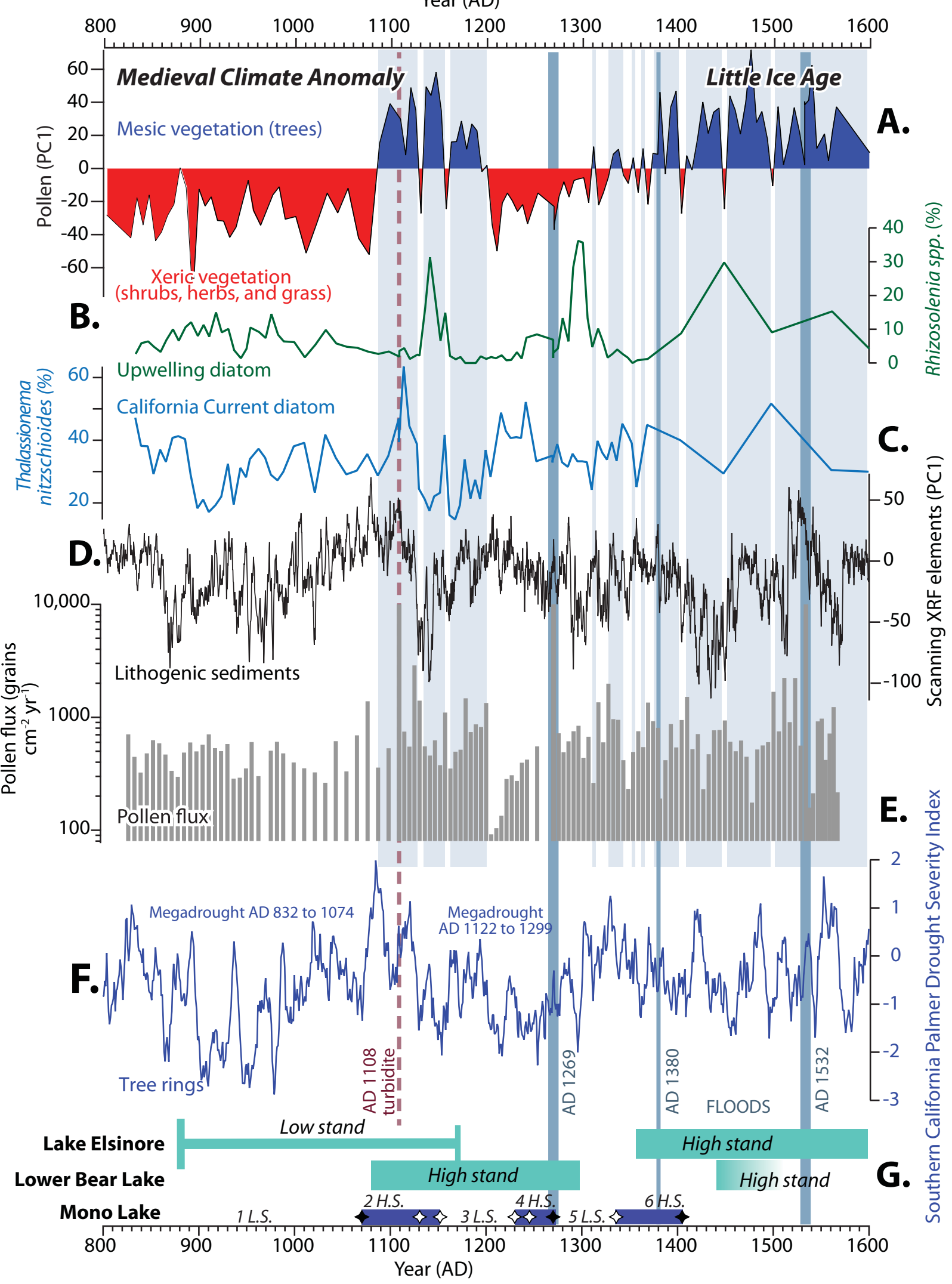